\title{
$\mathrm{COPD}$ 의 병태생리
}

\section{Pathophysiology of Chronic Obstructive Pulmonary Disease}

\begin{tabular}{l}
\hline 이 상 도 \\
\hline 울산의대 서울아산병원 내과 \\
\hline 서울 송파구 풍납동 388-1 \\
\hline Sang-Do Lee, M.D. \\
\hline Department of Internal Medicine \\
\hline University of Ulsan College of Medicine, Asan Medical Center \\
\hline E-mail : sdlee@amc.seoul.kr \\
\hline
\end{tabular}

\section{Abstract}

C

hronic obstructive pulmonary disease (COPD) is a chronic progressive disease that is characterized by irreversible airflow limitation with a partially reversible component. The pathologic abnormalities of COPD are associated with lung inflammation, an imbalance of proteinases and antiproteinases, and oxidative stress that are induced by noxious particles and gases in susceptible individuals. The physiologic changes of COPD are mucus hypersecretion, ciliary dysfunction, airflow limitation, pulmonary hyperinflation, gas exchange abnormalities, pulmonary hypertension, cor pulmonale, and systemic effects. The airflow limitation results principally from an increase in the resistance of the small conducting airways and a decrease in the pulmonary elastic recoil due to emphysematous lung destruction. This article provides a general overview of the pathophysiology of COPD.

$\overline{K e y w o r d s}$ : Chronic obstructive pulmonary disease; Chronic obstructive bronchitis; Emphysema; Airflow limitation; Pathophysiology

핵 심 용 어 : 만성폐쇄성폐질환; 만성 기관지염; 폐기종; 기류제한; 병태생리
서 론
$\square]$ 성폐쇄성폐질환(chronic obstructive pulmo-
nary disease, COPD)을 초래할 수 있는 유해한 흡입분진과 가스들은 폐에 염증을 일으킬 뿐만 아니라 조직의 파괴를 유발하며, 파괴를 최소화하기 위한 방어 기전 및 손상된 조직의 구조를 회복시키는 복구기전을 억제시킨다.

이러한 폐 조직의 손상에 의해 점액의 과분비, 기 도협착과 섬유화, 폐 실질의 파괴(폐기종) 및 혈관의 변화 등의 병리학적 이상이 생기며 그 결과 호기유량 의 감소와 $\mathrm{COPD}$ 에 특징적인 생리학적 이상들이 발 생한다.

$\mathrm{COPD}$ 의 병인에 관한 많은 정보는 동물실험 또는 생 체 외(in vitro) 연구를 통해 알려졌으나 여러가지 관점에 서 인간의 질병과는 달라 제한점이 존재한다. 한편 $\mathrm{COPD}$ 환자를 대상으로 한 병인 · 병리 · 병태생리 등의 연구에는 대상군의 선정, 환자 수의 제한, 조직 확보의 제 한성 등이 있어 이 질환의 병태생리를 이해하기에는 아직 부족한 점이 많다. 이러한 한계 하에서 현재까지 알려진 증거들을 중심으로 $\mathrm{COPD}$ 의 병태생리를 기술해 보고자 한다. 


\section{COPD의 병태생리}

$\mathrm{COPD}$ 의 병리학적 변화는 그에 상응하는 생리학적인 이상을 유발하며 초기에는 운동시에, 후기에는 안정시에 도 이상소견이 나타나게 된다. 질병의 특징적인 생리학적 인 변화로는 점액의 과분비, 섬모의 기능장애, 호흡 기류 의 제한, 폐 과팽창, 가스교환의 이상, 폐고혈압, 폐성심 등이 포함되며 질환이 진행함에 따라 순서대로 이러한 변 화들이 나타나게 된다. 그리고 이러한 다양한 생리학적인 변화에 의해 만성 기침, 객담의 분비, 호흡곤란 등 $\mathrm{COPD}$ 의 특징적인 증상들이 나타나게 된다(1).

\section{1. 점액 과분비와 섬모 기능장애}

$\mathrm{COPD}$ 에서 관찰되는 점액 과분비는 점액을 분비하는 선(gland) 자체가 커지거나 류코트리엔, 단백분해효소, 뉴로펩티드 등의 염증매개물질들에 의해 술잔세포( $\mathrm{gO}^{-}$ blet cell)수가 증가함으로써 발생한다. 또한 섬모가 존재 하는 상피세포들은 편평상피화생 (squamous metaplasia)을 일으켜 섬모운동을 통한 청소기능의 장애를 초래 한다. 이러한 변화들은 일반적으로 $\mathrm{COPD}$ 로 진행하는 최 초의 변화이며 다른 생리학적인 이상이 나타나기 이전에 수 년 동안 지속될 수 있다.

\section{2. 기류제한과 폐 과팽창}

호기시 기류제한은 $\mathrm{COPD}$ 에 있어서 특징적인 생리학 적 변화이다. $\mathrm{COPD}$ 에서 기류제한의 중요한 특징은 대부 분 비가역적이나 약간의 가역적인 부분을 가지고 있다는 점이다. 기류제한의 비가역적인 요소는 주로 고정된 기도 폐쇄와 그에 따른 기도저항의 증가를 유발하는 소기도의 개형(즉, 섬유화와 협착)에 의한 것으로 알려져 있다 (2 7). $\mathrm{COPD}$ 에서 기류제한을 유발하는 부위는 내경
$2 \mathrm{~mm}$ 이하인 기관지 및 세기관지를 포함하는 작은 전도 성 (conducting) 기도이다. 정상 폐에서는 소기도의 저항 이 전체기도저항의 작은 부분을 차지하지만 $\mathrm{COPD}$ 환자 에서는 전체 하부기도저항이 정상인에 비해 약 두배 가량 증가되어 있고 이러한 증가는 대부분이 말초 기도저항의 증가에 의한 것이다(5).

폐 실질의 파괴(폐기종, emphysema)는 기도의 비가 역적인 폐쇄에 큰 역할을 하지는 못하지만 몇 가지 기전 에 의해 호기류의 제한과 기도저항의 증가를 일으킨다. 폐포부착(alveolar attachments)의 파괴에 의해서 소기 도의 개방이 유지되지 못하고(8) 또한 폐포 자체의 파괴 에 의해 폐탄력반동(elastic recoil)의 소실이 발생하여 호기를 유도하는 폐포 내 압력의 감소를 일으킨다( 9 , 10). 지금까지 폐기종에 의해 발생하는 말초기도 외벽의 폐포부착의 파괴와 폐탄력반동의 소실이 말초기도 폐쇄 의 병인으로 알려져 있기는 하지만 $(8,10)$ 말초기도저항 을 직접적인 방법으로 측정해보면 말초기도벽의 구조적 인 변화가 $\mathrm{COPD}$ 에서의 말초기도저항 증가에 가장 중요 한 원인임을 알 수 있다(5).

기도평활근의 수축, 진행하는 기도염증, 기도 내 점 액 및 혈장삼출액의 축적 등은 아마 기류제한 기전 중 에서 작은 부분을 차지하며 치료에 의해 호전될 수 있 는 부분이다. $\mathrm{COPD}$ 의 악화시에는 염증과 점액 및 삼 출액의 축적이 특히 중요한 역할을 한다고 알려져 있다 (표 1)(11).

$\mathrm{COPD}$ 에서 기류제한은 폐활량측정법으로 가장 잘 측 정되고 진단과 치료에 있어서 판단의 기준이 된다. $\mathrm{COPD}$ 환자를 진단하고 추적하는 데 필수적인 폐활량 측 정치는 1 초간 노력성 호기량(forced expiratory volume in one second, $\mathrm{FEV}_{1}$ )과 노력성 폐활량(forced vital capacity, FVC)이다. COPD가 진행하면서 기도벽 두께 
표 1. Causes of Airflow Limitation in COPD

\begin{tabular}{ll}
\hline \multicolumn{1}{c}{ Irreversible } & \multicolumn{1}{c}{ Reversible } \\
\hline - Fibrosis and narrowing of airways & - Accumulation of inflammatory cells, mucus, and plasma \\
- Loss of elastic recoil due to alveolar destruction & exudate in bronchi \\
- Destruction of alveolar support that maintains patency of & $\cdot$ Smooth muscle contraction in peripheral and central airways \\
small airways & $\cdot$ Dynamic hyperinflation during exercise \\
\hline
\end{tabular}

의 증가, 폐포 부착의 소실, 폐탄성반동의 소실이 동반되 고 그에 따라 $\mathrm{FEV}_{1}$ 및 $\mathrm{FVC}$ 는 감소하게 된다. $\mathrm{FVC}$ 에 대 한 $\mathrm{FEV}_{1}$ 의 비 $\left(\mathrm{FEV}_{1} / \mathrm{FVC}\right)$ 의 감소는 진행하는 기류제 한의 최초의 소견으로 나타난다. $\mathrm{FEV}_{1}$ 은 연령증가와 함 께 자연적으로 감소하지만 일반적으로 $\mathrm{COPD}$ 환자의 감 소율은 정상인에 비해서 더 크다.

기류제한이 심해짐에 따라 호기는 평상호흡(tidal breathing) 동안에 유량이 제한된다. 질병의 초기에는 이러한 현상이 운동시에만 나타나지만 나중에는 안정시 에도 나타나게 된다. 동시에 폐 탄성의 감소, 조기 기도폐 쇄, 손상된 폐 역학에 적응하기 위해 변형된 호흡양식을 반영하는 다양한 역동적인 요소들의 상호작용에 의해 기 능적 잔기량(functional residual capacity, $\mathrm{FRC}$ )이 증 가하게 된다. 기류제한이 진행함에 따라 폐 내의 공기를 밖으로 내보내는 데 많은 시간이 필요하지만 이어지는 흡기노력에 의해 호기가 충분히 이루어지지 못하고 폐 내에 공기가 축적되어 결국 동적 과팽창(dynamic hyperinflation)이 초래된다. 또한 기능적 잔기량의 증 가는 흡기근의 기능 및 협조의 장애를 유발한다. 이러한 변화는 질병이 진행함에 따라 발생하지만 질병의 초기에 도 운동시에는 거의 항상 관찰된다. 운동시에는 환기가 필요한 대사산물이 증가되므로 환기를 위한 여러 장치들 의 자극이 증가되어 충분한 호기를 더욱 어렵게 만들기 때문이다.

\section{3. 가스교환의 이상}

$\mathrm{COPD}$ 가 진행됨에 따라 말초기도의 폐쇄, 폐 실질의 파괴, 폐혈관의 이상 등으로 폐의 가스교환능력이 감소하 게 되어 저산소혈증이 발생하며 결국에는 고탄산혈증으 로 이어진다. 기본 폐기능검사와 동맥혈가스결과와의 상 호관련성은 약하지만 $\mathrm{FEV}_{1}$ 이 $1 \mathrm{~L}$ 이상인 경우에는 의미 있는 저산소혈증이나 고탄산혈증의 발생은 드물다(12). 저산소혈증은 질병의 초기에는 운동시에만 발생하지만 질병이 진행함에 따라 안정시에도 나타나게 된다.

$\mathrm{COPD}$ 에서 병기와 관계없이 저산소혈증의 주요한 기 전은 환기-관류의 불균형이다(13). 세기관지의 염증과 환기분포 사이의 의미있는 연관성이 시사하듯이 말초기 도에서는 기도벽의 손상이 환기-관류 불균형과 관련되 어 있다. 폐 실질에서는 폐기종에 의한 폐포 표면적의 감 소로 폐확산능이 감소하고 가스교환에 장애를 받는다 (14). 그러므로 높은 환기-관류비는 폐포의 파괴와 폐혈 관의 소실을 반영하는 폐기종성 변화가 심함을 나타낸다. 폐기종의 중증도는 가스교환 장치로서 폐의 전체적인 비 효율성과 관련된 것으로 보인다. 이는 폐포용적당 일산화 탄소의 확산능 $(\mathrm{DLco} / \mathrm{VA})$ 과 육안적인 폐기종의 중증도 의 상관관계가 높은 것으로 설명될 수 있다. 폐기종에서 폐탄력반동의 소실로 인한 환기의 감소는 모세혈관의 소 실과 환기의 전반적인 불균등과 함께 환기-관류 불균형 을 초래하고 결국 저산소혈증을 일으키게 된다. 
폐혈관의 이상과 환기-관류 불균형의 연관성에 대하 여 중증도가 경한 $\mathrm{COPD}$ 환자들을 대상으로 한 연구에 따르면 폐혈관 벽의 손상이 심할수록 산소투여에 의한 저 산소성 혈관수축의 회복능력이 떨어진다고 한다(15). 이 러한 점은 폐동맥 벽의 병리적 이상이(특히 내막층이 영 향을 받았을 때) 환기-관류 불균형을 초래하는 저산소 증에 대한 혈관반응의 소실을 결정하는 데 매우 중요한 역할을 한다는 것을 시사한다. 만성적인 고탄산혈증은 일 반적으로 흡기근육의 기능장애와 폐포의 저환기를 반영 한다.

\section{4. 폐고혈압과 폐성심(Cor Pulmonale)}

폐고혈압은 $\mathrm{COPD}$ 경과중의 말기에(very severe $\mathrm{COPD})$ 나타나게 되며, 대개 심한 저산소혈증 $\left(\mathrm{PaO}_{2}\right.$ $<60 \mathrm{mmHg}$ ) 이후에 발생하고 종종 고탄산혈증 이후에 도 나타난다. 폐고혈압은 $\mathrm{COPD}$ 의 주요한 심혈관계 합병 증이며 폐성심으로의 진행 및 불량한 예후와 관련되어 있 다(16). 안정시 $\mathrm{COPD}$ 환자의 폐동맥압은 질병의 중등도 가 심해도 대개 약간만 상승되어 있다. 하지만 운동을 하 는 경우에는 현저히 상승한다.

$\mathrm{COPD}$ 환자에서 폐고혈압의 진행은 치료를 받지 않더 라도 느린 것으로 알려져 있다. $\mathrm{COPD}$ 환자군을 평균 5 년 이상 추적 관찰한 폐동맥압의 변화에 대한 연구에서 평균 폐동맥압의 상승은 연간 $3 \mathrm{mmHg}$ 에 불과했고, 단지 $33 \%$ 의 환자에서만 평균 폐동맥압이 이 기간 동안 연간 $5 \mathrm{mmHg}$ 이상 증가했다. 폐고혈압이 진행되었던 환자들 (평균 폐동맥압의 증가가 연간 $5 \mathrm{mmHg}$ 이상일 경우로 정의하였음)은 전체 그룹과 기초 폐기능검사, 동맥혈가 스분석, 폐 혈역학적 수치에서 유사하게 관찰되었다. 그 러나 대상환자들은 진행되는 저산소혈증과 고탄산혈증에 의해 구별되었고, 반면에 폐동맥압이 안정적인 환자들은
동맥혈가스분석에서 변화가 없었다. 여러 연구를 통해서 저산소혈증을 보이는 $\mathrm{COPD}$ 환자에서 폐고혈압 또는 말 초 부종의 존재는 생존율과 관련이 있음이 증명되었다. 폐고혈압이 $\mathrm{COPD}$ 환자에서 서서히 진행한다고 하더라 도 폐고혈압의 존재는 불량한 예후를 시사한다. 평균 폐 동맥압이 정상인 $(<20 \mathrm{mmHg})$ 환자에서 4 년 생존율은 $77 \%$ 이나 폐동맥압이 상승된 환자의 4년 생존율은 $44 \%$ 로 큰 차이를 보였다. 또한 말초부종이 발생한 $\mathrm{COPD}$ 환 자는 5년 생존율이 단지 27 33\%에 불과했다.

폐고혈압의 발생에 관여하는 인자로는 혈관수축, 폐동 맥의 구조재형성(remodeling)에 의한 폐혈관벽 두께의 증가 및 내경의 감소, 폐기종에 의한 모세혈관의 파괴로 인한 폐 관류 압력의 증가 등을 들 수 있다. 폐혈관수축 자체에 관여하는 기전도 다양하며 이러한 기전으로는 저 산소증에 의한 폐혈관 평활근 수축, 산화질소(nitric oxide)의 합성이나 분비의 감소와 같은 혈관내피세포에 의존하는 혈관확장기전의 손상, 혈관수축관련 펩티드들 (염증 관련 세포에서 분비되는 엔도텔린-1 등)의 비정 상적인 분비 등이 있다. 진행된 $\mathrm{COPD}$ 에서 저산소증은 폐동맥의 수축 및 폐혈관 벽의 재형성(성장인자 분비의 유도(17) 또는 저산소증에 의한 혈관수축으로 인한 기계 적인 압력의 결과로서)의 촉진 등을 통해 폐고혈압의 형 성에 일차적인 역할을 하게 된다.

폐성심은 “선천성 심장 질환처럼 주로 좌심실에 영향 을 주는 질환에 의해 발생한 경우를 제외한, 폐의 구조 나 기능에 영향을 미치는 폐질환에 의해 초래되는 우심 실의 비대"로 정의한다. 폐성심은 병리학적인 정의로서 생존시에는 임상적으로 진단을 내리고 평가하기가 어려 워 아직까지 발병률 및 자연경과에 대해서 잘 알려지지 않았다. 폐성심은 $\mathrm{COPD}$ 환자에서 기류제한이 악화될 수록 유병률이 더 증가한다. $\mathrm{FEV}_{1}<1.0 \mathrm{~L}$ 인 환자의 경 
우 약 $44 \%$ 에서 폐성심이 관찰되며, $\mathrm{FEV}_{1}<0.6 \mathrm{~L}$ 인 환 자의 경우 약 $70 \%$ 로 증가되어 관찰된다. 폐성심의 유병 률은 또한 고이산화탄소혈증, 저산소혈증 그리고 적혈구 증다증에서 높은 것으로 알려져 있다. 폐고혈압과 폐기 종에 의한 폐혈관의 감소가 우심실 비대 및 우심부전을 초래할 수는 있지만 어떤 환자에서는 폐고혈압의 존재에 도 불구하고 우심실 기능이 잘 보존되는 경우도 있다 (18). 우심부전은 정맥의 울혈 및 혈전의 발생과 관련되 며 폐색전증을 유발하여 폐순환장애를 더욱 악화시킬 수 있다.

\section{5. 병태생리와 COPD의 증상}

만성 기관지염의 증상인 만성 기침과 객담배출은 기도 염증의 결과이다. 기도염증은 점액의 과분비 및 정상적인 섬모운동에 의한 청소기능의 장애를 초래하게 된다. $\mathrm{COPD}$ 환자에서의 객담은 염증반응의 결과로서 생성되 어지는 것이며 기관지순환의 미세혈관들로부터 삼출된 혈장단백, 염증세포들, 폐포상피의 술잔세포로부터 나오 는 소량의 점액으로 구성된다. 생성되는 객담의 양이 정 상적인 청소기능으로 해결할 수 있는 양보다 많을 경우 기침과 객담배출이 발생하게 된다. 점막하 선의 염증, 선 세포의 과증식과 같은 몇몇 병리적인 이상도 만성적인 객 담배출에 영향을 주지만 이러한 변화는 객담배출을 호소 하는 모든 환자에게 나타나는 것은 아니다.

호흡 활동의 비정상적인 자각으로 알려진 호흡곤란은 호흡근에 대한 신경적 동인(drive)과 그에 의한 환기의 유효성 간의 불균형으로 인해 발생한다. 개개인에 따라 숨찬 느낌을 묘사하는 데 있어서 각기 다른 용어를 사용 하며 감정 등과 같은 다른 요인에 의해서도 표현은 달라 진다. $\mathrm{COPD}$ 환자에서 호흡곤란은 주로 기도저항의 증가 와 폐탄성반동의 감소 등 폐 역학 장애의 결과로서 발생
한다고 알려져 있다. 호흡곤란이 질병의 초기에는 주로 과격한 운동을 할 때에만 발생하지만 폐의 기계적인 장애 가 심해지면 안정시에도 나타나게 될 것이다.

\section{6. 급성 악화의 병리 및 병태생리}

\section{1) 병 리}

급성 악화시에는 $\mathrm{COPD}$ 환자가 검사를 할 수 없을 정 도로 상태가 좋지 않기 때문에 급성 악화의 병리변화를 기저질환의 병리변화와 구분하는 것은 힘들다. 몇몇 제한 적인 연구에 의하면 경증 $\mathrm{COPD}$ 악화시에는 객담과 조직 모두에서 중성구와 호산구가 증가된 것을 관찰할 수 있었 고 중증 악화시에는 객담에서 중성구와 호산구가 증가된 것을 관찰할 수 있었다 $(19,20)$. 최소한 객담에서는 $\mathrm{COPD}$ 의 악화 동안에 관찰할 수 있는 염증세포들의 변화가 천식 악화시와 유사한 것을 관찰할 수 있었다(21 25).

\section{2) 병태생리}

호기시의 기류는 경증 악화시에는 거의 변화되지 않으 며 (19) 중증 악화시에만 약간 감소할 수 있다 $(26,27)$. 악 화의 병태생리는 아직 완전히 밝혀지지는 않았지만 중증 악화의 일차적인 생리학적인 변화는 주로 환기-관류 불 균형의 증가로 인한 가스교환의 악화이다. 환기-관류 불 균형이 증가됨에 따라 호흡근의 일은 증가되고 산소 소비 량이 증가하게 되며 혼합정맥혈산소분압이 감소하여 가 스교환의 장애가 더욱 심화된다(26). 환기-관류 불균형 의 악화에는 여러 인자가 관여하는데, 기도의 염증과 부 종, 점액의 과분비, 기관지수축 등은 환기분포의 변화를 초래하게 되고, 한편 저산소증에 의한 폐동맥의 수축은 관류의 분포를 변화시키게 된다. 가스교환을 악화시키는 추가적인 요인들로는 호흡형태(pattern)의 이상 및 호흡 근의 피로를 들 수 있다. 이러한 요인들은 혈액가스와 호 
흡성 산증의 악화를 초래하고 심각한 호흡부전과 사망에 까지 이르게 할 수 있다(26 29). 또한 폐포 저환기는 저 산소혈증, 고탄산혈증, 호흡성 산증을 일으킬 수 있으며, 저산소혈증과 호흡성 산증은 폐혈관수축을 촉진시켜 폐 동맥압을 증가시키고 우심실부하를 가중시키게 된다.

\section{요 약}

$\mathrm{COPD}$ 는 비가역적인 기류제한을 특징으로 하는 질병 의 상태이다. 이러한 기류제한은 유해입자나 가스 등에 대한 폐의 비정상적인 염증반응과 관련되어 있고 자연경 과 중 지속적으로 진행하는 양상을 떤다. 비정상적인 염 증반응 및 단백분해효소와 항단백분해효소 간의 불균형 과 산화 스트레스 등의 기전에 의해 점액의 과분비, 섬모 의 기능장애, 소기도의 섬유화와 협착, 폐실질의 파괴, 폐 혈관 손상 등이 발생한다. 이러한 병리학적 변화에 의해 기류제한이 발생하고 가스교환장애, 폐고혈압, 폐성심, 전신적인 염증이나 골격근의 기능장애 등이 유발된다. $\mathrm{COPD}$ 환자의 일반적인 증상인 기침, 객담, 호흡곤란 등 은 이러한 병태생리학적 변화로 설명할 수 있다. 옹

\section{참 고 문 헌}

1. Pauwels RA, Buist AS, Calverley PMA, Jenkins CR, Hurd SS. Global strategy for the diagnosis, management and prevention of chronic obstructive pulmonary disease. NHLBIMHO Global Initiative for Chronic Obstructive Lung Disease (GOLD) Workshop summary. Am J Respir Crit Care Med 2001; 163: 1256 76

2. Mullen JB, Wright JL, Wiggs BR, Pare PD, Hogg JC. Reassess- ment of inflammation of airways in chronic bronchitis. BMJ (Clin Res Ed) 1985; 291: 1235 - 9

3. Cosio M, Ghezzo H, Hogg JC, Corbin R, Loveland M, Dosman $\mathrm{J}$, et al. The relations between structural changes in small airways and pulmonary-function tests. N Engl J Med 1978; 298: $1277-81$

4. Matsuba K, Thurlbeck WM. The number and dimensions of small airways in emphysematous lungs. Am J Pathol 1972; 67: $265-75$

5. Hogg JC, Macklem PT, Thurlbeck WM. Site and nature of airway obstruction in chronic obstructive lung disease. N Engl J Med 1968; 278: $1355-60$

6. Kuwano K, Bosken CH, Pare PD, Bai TR, Wiggs BR, Hogg JC. Small airways dimensions in asthma and in chronic obstructive pulmonary disease. Am Rev Respir Dis 1993; 148: 1220 - 5

7. Matsuba K, Wright JL, Wiggs BR, Pare PD, Hogg JC. The changes in airways structure associated with reduced forced expiratory volume in one second. Eur Respir J 1989; 2: 834 - 9

8. Dayman H. Mechanics of airflow in health and emphysema. J Clin Invest 1951; 30: 1175 - 90

9. Butler J, Caro CG, Alcala R, Dubois AB. Physiological factors affecting respiratory resistance in normal subjects and in patients with obstructive airways disease. J Clin Invest 1960; 39: $584-91$

10. Mead J, Turner JM, Macklem PT, Little JB. Significance of the relationship between lung recoil and maximum expiratory flow. J Appl Physiol 1967; 22: 95 - 108

11. Burnett D, Stockley RA. Serum and sputum alpha 2 macroglobulin in patients with chronic obstructive airways disease. Thorax 1981; 36: 512 - 6

12. Lane DJ, Howell JB, Giblin B. Relation between airways 
obstruction and $\mathrm{CO} 2$ tension in chronic obstructive airways disease. BMJ 1968; 3: 707 - 9

13. Rodriguez-Roisin R, MacNee W. Pathophysiology of chronic obstructive pulmonary disease. In: Postma DS, Siafakas MN, eds. Management of chronic obstructive pulmonary disease. European Respiratory Monograph 1998; 3: 107 - 26

14. McLean A, Warren PM, Gillooly M, MacNee W, Lamb D. Microscopic and macroscopic measurements of emphysema: relation to carbon monoxide gas transfer. Thorax 1992; 47: $144-9$

15. Barbera JA, Riverola A, Roca J, Ramirez J, Wagner PD, Ros D, et al. Pulmonary vascular abnormalities and ventilation - perfusion relationships in mild chronic obstructive pulmonary disease. Am J Respir Crit Care Med 1994; 149: 423 - 9

16. MacNee W. Pathophysiology of cor pulmonale in chronic obstructive pulmonary disease. Part two. Am J Respir Crit Care Med 1994; 150: $1158-68$

17. Knighton DR, Hunt TK, Scheuenstuhl H, Halliday BJ, Werb Z, Banda MJ. Oxygen tension regulates the expression of angiogenesis factor by macrophages. Science 1983; 221: 1283 - 5

18. Biernacki W, Flenley DC, Muir AL, MacNee W. Pulmonary hypertension and right ventricular function in patients with COPD. Chest 1988; 94: $1169-75$

19. Saetta M, Di Stefano A, Maestrelli P, Turato G, Ruggieri MP, Roggeri A, et al. Airway eosinophilia in chronic bronchitis during exacerbations. Am J Respir Crit Care Med 1994; 150: $1646-52$

20. Saetta M, Di Stefano A, Maestrelli P, Turato G, Mapp CE,
Pieno $\mathrm{M}$, et al. Airway eosinophilia and expression of interleukin -5 protein in asthma and in exacerbations of chronic bronchitis. Clin Exp Allergy 1996; 26: 766 - 74

21. Pizzichini MM, Pizzichini E, Efthimiadis A, Clelland L, Mahony JB, Dolovich J, et al. Markers of inflammation in induced sputum in acute bronchitis caused by Chlamydia pneumoniae. Thorax 1997; 52: 929 - 31; discussion 926 - 7

22. Pizzichini E, Pizzichini MM, Gibson P, Parameswaran K, Gleich GJ, Berman L, et al. Sputum eosinophilia predicts benefit from prednisone in smokers with chronic obstructive bronchitis. Am J Respir Crit Care Med 1998; 158: 1511 - 7

23. Maestrelli P, Saetta M, Di Stefano A, Calcagni PG, Turato G, Ruggieri MP, et al. Comparison of leukocyte counts in sputum, bronchial biopsies, and bronchoalveolar lavage. Am J Respir Crit Care Med 1995; 152: 1926 - 31

24. Turner MO, Hussack P, Sears MR, Dolovich J, Hargreave FE. Exacerbations of asthma without sputum eosinophilia. Thorax 1995; 50: $1057-61$

25. Fahy JV, Kim KW, Liu J, Boushey HA. Prominent neutrophilic inflammation in sputum from subjects with asthma exacerbation. J Allergy Clin Immunol 1995; 95: 843 - 52

26. Barbera JA, Roca J, Ferrer A, Felez MA, Diaz O, Roger N, et al. Mechanisms of worsening gas exchange during acute exacerbations of chronic obstructive pulmonary disease. Eur Respir J 1997; 10: 1285 - 91

27. Seemungal TA, Donaldson GC, Bhowmik A, Jeffries DJ, Wedzicha JA. Time course and recovery of exacerbations in patients with chronic obstructive pulmonary disease. Am J 
Respir Crit Care Med 2000; 161: 1608 - 13

28. Schmidt GA, Hall JB. Acute or chronic respiratory failure.

Assessment and management of patients with COPD in the emergency setting. JAMA 1989; 261: 3444 - 53

29. Rodriguez-Roisin R. Pulmonary gas exchange in acute respiratory failure. Eur J Anaesthesiol 1994; 11: 5 - 13

\section{Peer Reviewer Commentary}

\section{김 세 규 (연세의대 내과)}

$\mathrm{COPD}$ 는 전 세계적으로 사망과 경제적-사회적 질병 부담의 중요한 원인이 되고 있으며, 우리나라에서도 흡연자의 비율이 높고, 공기 오염 등 환경 오염으로 인하여 $\mathrm{COPD}$ 의 유병률이 점차 증가할 것으로 추정된다. 따라서 $\mathrm{COPD}$ 의 이환율, 사망률 등을 감소시키고 예방 대책을 강구하기 위해서는 근본적인 병태생리에 대한 파악이 가장 기본적이며, 무엇보다 중요한 과정이지만 최근 많은 연구 노력에도 불구하고 아직도 명확한 기전이 밝혀지지 않은 부분이 많다. 본 논문은 $\mathrm{COPD}$ 의 병인, 병리, 병태생리 등에 관한 많은 연구 보고들을 현재까지 알려진 증거들을 중심으로 체계적 으로 정리하여 기술하였다.

\section{자율학습 3월호 (두경부 종물의 감별진단) 정답}

1. (4)

2. (3)

3. (3)

4. (2)

5. (2)
6. (4)

7. (4)

8. (1)

9. (1)

10. (4) 